\title{
PERFORMANCE AND EMISSIONS OF A VESSEL TURBINE FUELED WITH MARINE AND ASPIRE OIL METHYL ESTER MIXTURES
}

\author{
Burak GÖKALP1,* \\ ${ }^{I}$ Ministry of Defence, Naval Shipyard, 41650, Kocaeli, Turkey
}

\begin{abstract}
In this experimental case, a vessel G/T was run with marine fuel (MF)/aspires oil methyl ester (AME) mixtures. The blends tested were marine fuel (MF), $50 \%$ of aspire oil methyl ester, $100 \%$ of aspire oil methyl ester (AME), and $100 \%$ of MF by volume. The G/T was operated at 4 loads, $20 \%, 60 \%, 80 \%$ and $100 \%$. Turbine power generation and emissions performance were tested. The results that AME content in the fuel mixture increased, the fuel flow rate increased to maintain the constant speed operation and equivalence ratio reduced. The results of tested that turbine can operate with AME blends in MF without any modification. Exhaust gas temperatures reduced with increasing AME content. Higher AME blends resulted in lower CO2, $\mathrm{CO}$ emissions while NOx emissions increasing. Finally, various energetic performance parameters of the engine were evaluated and compared with each other. This study shows that a turbine engine can be operated successfully with marine fuel (MF) and aspire oil methyl ester (AME) mixtures.
\end{abstract}

Keywords: Turbine, Marine fuel, Aspire oil methyl ester, Emission.

\section{ASPIR METIL ESTERİ VE KARŞIMLARININ BİR GEMI TÜRBİN MOTORUNDAKI PERFORMANS VE EMISYONLARI}

\section{ÖZET}

Bu deneysel çalışmada, deniz yakıtı (MF) ile bir gemi gazı türbini (G/T), deniz yakıtı (MF) / aspire yağ metil ester (AME) karışımları ile bir çalışma gerçekleştirildi. (\% 50 aspire yağı metil esteri,\% 100 aspire yağı metil esteri (AME) ve\% 100 MF miktarında) G / T, dört farklı yükte, $\% 20, \% 60, \% 80$ ve \% 100 gaz türbini çalıştırıldı. Güç üretimi ve emisyonlar, performans test edildi. Sonuçlar, türbinin herhangi bir değişiklik yapmadan AME karışımları ile çalışabileceğini göstermiştir. AME içeriği artıkça egzoz gazı sıcaklıkları, düşük $\mathrm{CO} 2, \mathrm{CO}$ emisyonlarındaki karışımlarda daha yüksek oranda AME, NOx emisyonları artmıştır. Sonunda, çeşitli devirlerde gaz türbininin performans parametreleri değerlendirildi ve birbirleriyle karşılaştırıldı. Bu çalışma, bir türbin motorunun deniz yakıtı (MF) ve aspire yă̆ metil ester (AME) karışımları ile başarıyla çalıştırılabileceğini göstermiştir.

Anahtar kelimeler: Türbin, Deniz yakıtı, Aspir yağı metil esteri, Emisyon

\section{INTRODUCTION}

$\mathrm{G} / \mathrm{T}$ is used in vast industrial area (aviation and land industrial system). Aviation G/T usually uses kerosene and MF (in navy applications) $[1,2]$. When the power generation requires, G/T operation is usefull because of the reliability, compactness, higher power-to-weight ratio, lower emissions, ease of operation and maintenance, and especially fuel flexibility. Because of this reasons, $\mathrm{G} / \mathrm{T}$ is very compatible for the power production and the heat/power systems $[3,4]$.

In the last century world energy consumption has been increasing considerably. Biofuels have became as an alternative sources of energy [4]. Biodiesel is produced via transesterification of vegetable oils or animal fats by replacing the triglyceride molecules with an alcohol [5]. Since diesel fuel is commonly used in G/T, biodiesel and their fuel blends with diesel fuel were tested to explain the effects of biodiesel on the performance of the G/T [6]. Biodiesel formula is $\mathrm{C}$ neutral which no $\mathrm{CO} 2$ emitted during its process. It is absorbed during the production of the biodiesel. Biodiesel is non-toxic, few polluting to environment when discharged, has high lubricity, and not contain aromatics or sulfur. However, biodiesel has lower energy content and higher viscosity and cloud point compared to diesel fuels [7]. The main goal of the biodiesel is to replace fossil fuels reducing mainly the amount of $\mathrm{CO} 2$ emitted into the atmosphere. Most of G/T runs in high efficient combined power plants and few of them use an integrated section $[8,9,10]$. 
B. Gökalp

Biodiesel and its blends show similar thermal performance compared to diesel fuel with slightly higher CO and lower NOx emissions $[11,12]$. Petroleum fuels have always advantages due to their high energy content per each volume. However, combustion of petroleum fuels produces serious environmental consequences. CO2 emissions result in greenhouse effect and global warming. Pollutants of CO, HC, NOx, SO2 and soot are emitted to the atmosphere with negative outcomes [13].

Biodiesel uses in G/T have also been studied. Although the fuel consumption increased slightly with the addition of biodiesel in its blends, biodiesel showed a comparable performance to marine fuel $[14,15,16,17]$.

\section{THEORY/CALCULATION}

The combustion test was performed in Figure 1 with different loads conditions. Fuel and lubricating oil flow rates are measured by G/T flowmeters. Temperatures, all pressures at the compressor/turbine exit and exhaust temperatures are measured. The blends tested were MF, $50 \%$ of aspire oil methyl ester, $100 \%$ of AME, and $100 \%$ of MF. The turbine was run at 4 loads, $20 \%, 60 \%, 80 \%$ and $100 \%$. G/T power out-put and emissions were tested. CO2, CO, and NOx emissions are measured with an analyzer. A photograph of the G/T is given in Figure 2 on the other side the control room and data collect system are shown in Figure 3.

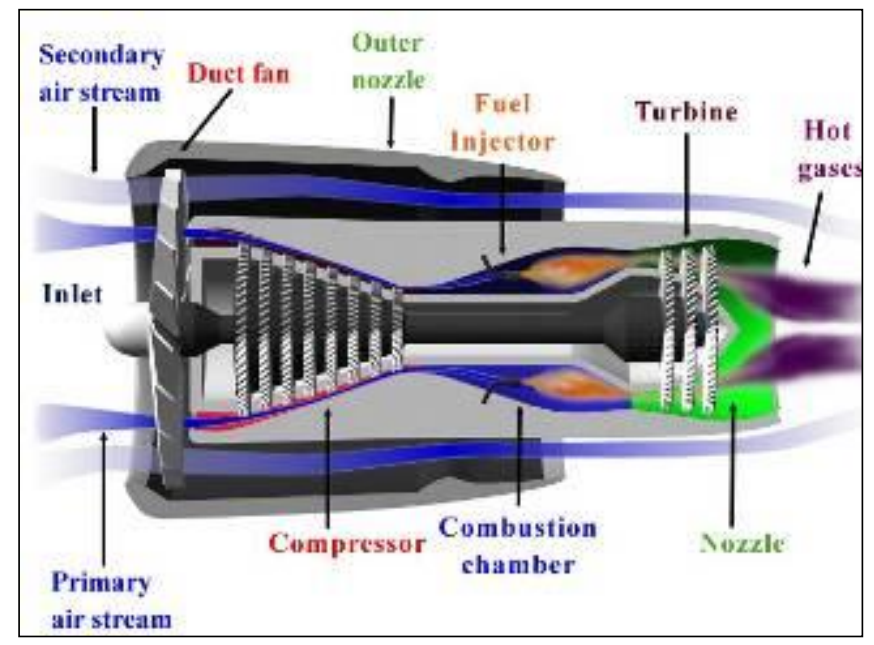

Figure 1. The schematic layout of the experimental setup.
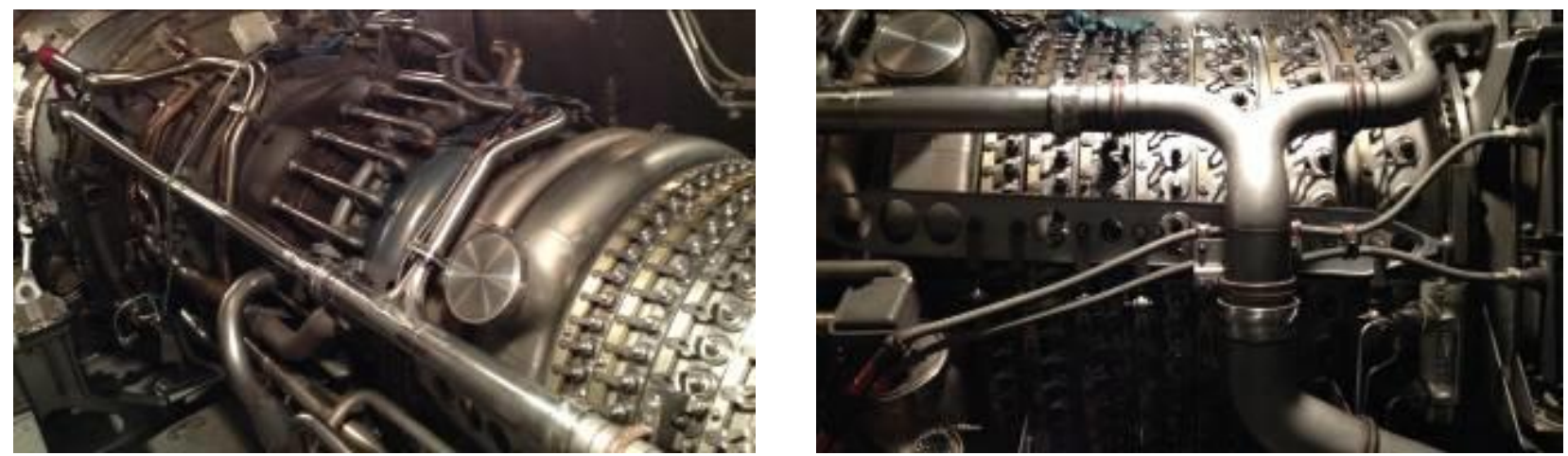

Figure 2. The photographs of the engine and the instrumentation. 

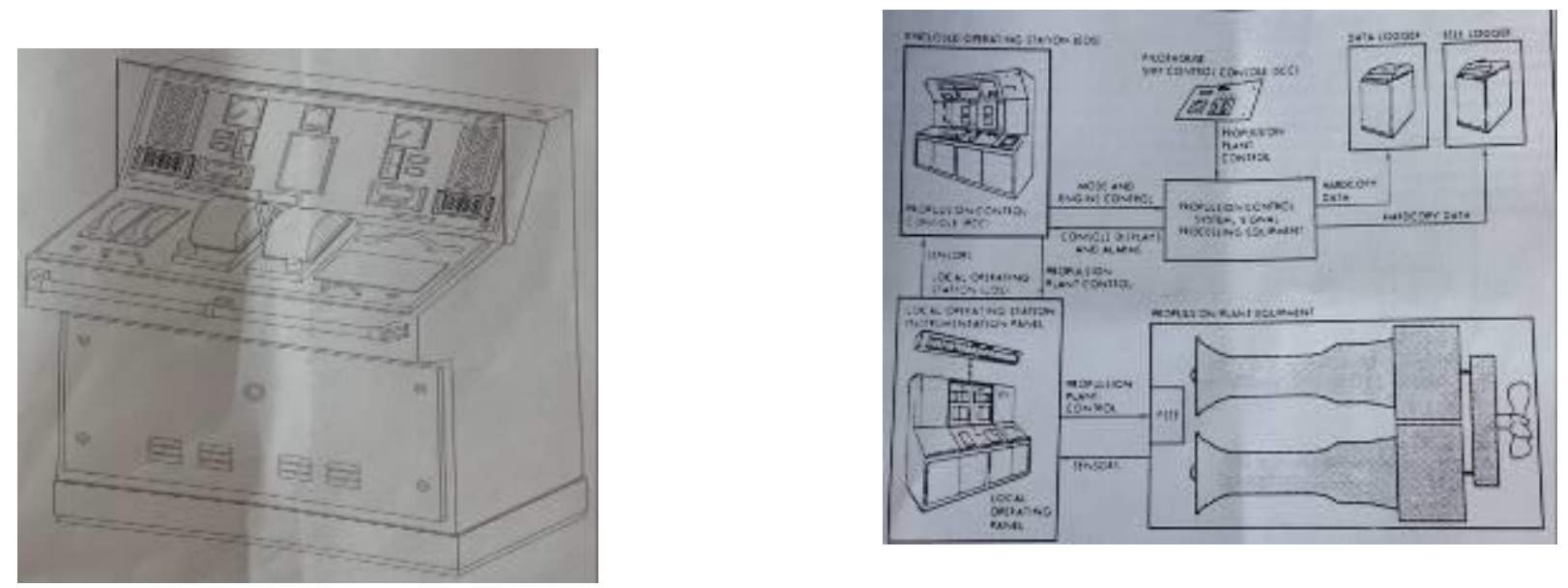

Figure 3. Control room and data acquisition system.

The load of the engine was controlled by the load control system. The exhaust temperature was measured using a thermocouple connected to the exhaust manifold. The exhaust emissions using a gas analyzer were measured. The specification of the emission analyzer is summarized in Table 1.

Table 1. Specification of the MEXA 574-GE emission analyzer.

\begin{tabular}{llll}
\hline Emission & NOx & CO & CO2 \\
\hline Operating range (ppm) & $0-5000$ & $0-10$ & $0-20$ \\
Accuracy (ppm) & 0.050 & 0.01 & 0.02 \\
\hline
\end{tabular}

In these tests; the engine was operated at 4 different loads. During the test period, the coolant, lubricating oil and exhaust temperatures, fuel consumption rate and exhaust emissions were recorded. The data collecting system was installed on the engine. It held Windows based software on a monitor system. The details of properties of the experimental fuels are summarized in Table 2.

Table 2. Properties of the experimental fuels (SI units).

\begin{tabular}{llll}
\hline Fuel Property & Method & AME & MF \\
\hline Density $\left(\mathrm{kg} / \mathrm{m}^{3}, 15^{\circ} \mathrm{C}\right)$ & ASTM D1298 & 881 & 830 \\
Viscosity $\left(\mathrm{cSt}, 40^{\circ} \mathrm{C}\right)$ & ASTM D 445 & 4.173 & 3.7 \\
Heating Value $(\mathrm{kJ} / \mathrm{kg})$ & ASTM D 4809 & 37388 & 44308 \\
Cetane Number & ASTM D 976 & - & 45 \\
& ASTM D 613 & 50 & - \\
Sulfur (wt. \%) & ASTM D 4294 & - & 0.29 \\
Flash Point $\left({ }^{\circ} \mathrm{C}\right)$ & ASTM D 93 & 105 & 75 \\
Cloud Point $\left({ }^{\circ} \mathrm{C}\right)$ & ASTM D 97 & - & -6 \\
& ASTM D 2500 & -3 & - \\
Particulate Matter (mg/L) & ASTM D 5452 & - & 3 \\
\hline
\end{tabular}




\section{DISCUSSION}

At constant speed, air mass flow ratio doesn't change with biodiesel content in the blend. The oxygen in biodiesel molecules results in leaner combustion and lower equivalence ratios. At all loads, air mass flow ratio doesn't change with AME content in the blend. The thrust increases with load and AME content does not reduce the thrust. These results show that G/T can run with AME blends in MF without modification. Exhaust temperature variation with biodiesel content is shown in Figure 4. Exhaust temperatures shows slight reduction with increasing biodiesel content, which may be attributed to lower adiabatic flame temperatures associated with increasing biodiesel content. The inlet gas temperature distributions of turbine combustion tests, showing that the temperature distributions are similar to each other. The $\mathrm{CN}$ of the fuel is important parameter which is responsible for the delay period. The fuel of higher cetane number gives lower delay period and provides smoother engine operation.

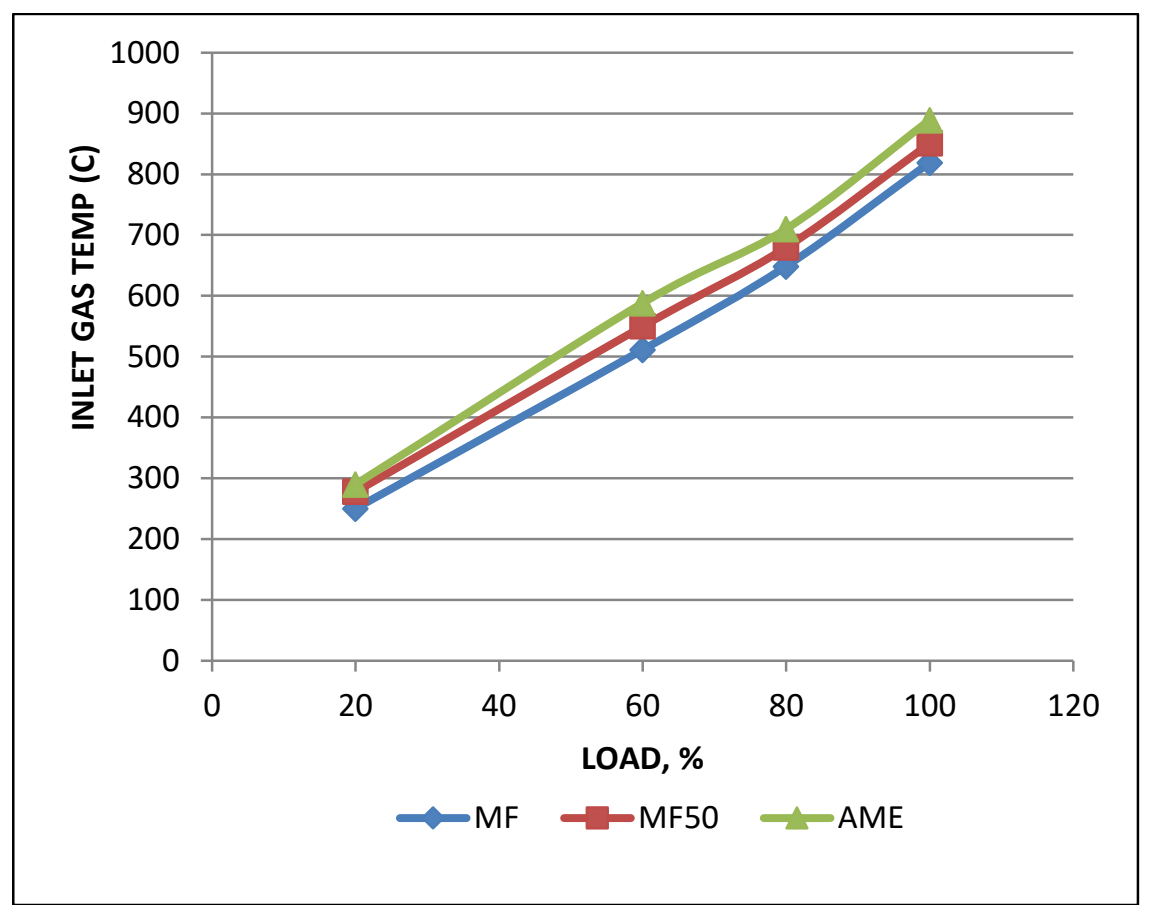

Figure 4. Inlet gas temperature variation.

Increased fuel flow rates result in higher presence of $\mathrm{C}$ containing in the combustion chamber, which produces higher concentrations of $\mathrm{CO} 2, \mathrm{CO}$ and $\mathrm{NOx}$ emissions. Figure 5 shows $\mathrm{CO} 2, \mathrm{CO}, \mathrm{NOx}$ emissions with engine speed and AME content. It is clear that increased AME content results in higher NOx but lower CO2 and CO. Similarly, as the engine speed increases, so do $\mathrm{CO}$ 2, $\mathrm{CO}$ and NOx emissions, which is attributed to higher fuel flow rates associated with higher engine speeds. This is considered as the consequence of utilizing a vaporizer to mix the fuel with incoming air instead of an injector, which leads to lower atomization and evaporation rates. Compared with MF, the NOx emission of the AME was increased by $8 \%$. The NOx emissions are determined by equivalence ratio, oxygen concentration, combustion temperature and time. The NOx increase in the emissions may be connected with the oxygen content of the biodiesel, since the fuel oxygen may become additional oxygen for NOx formation. In the literature, also reported that the NOx emission increased for the biodiesel fuels. NOx emissions increased with oxygen content.

The data acquire are compatible with the literature. Due to inadequate oxygen in the combustion chamber of the fuel, $\mathrm{CO}$ is formed. The ratio of $\mathrm{CO}$ in the rich region is higher than observed $\mathrm{CO}$ after the decline. $\mathrm{CO}$ emission is an indication of the chemical energy losses in the engine. At all loads and all mixtures, $\mathrm{CO}$ emissions increased and fuel consumption decreased with increasing AME content. The main reason is that AME contains $10 \% \mathrm{O} 2$ and no sulphur. The decrease in CO emission in biodiesel mixture causes the air-fuel ratio to improve. Thats why, $\mathrm{CO}$ emission for AME with increasing specific fuel consumption of the fuel mixture. $\mathrm{CO} 2$ emissions are one of the most important environmental problems throughout the world, as where the increase in atmospheric $\mathrm{CO}$ is a greenhouse effect to global warming. Biodiesel does not cause greenhouse gases in the atmosphere. Plants are the raw material for biodiesel; the question of whether burning biodiesel plants causes carbon dioxide to be absorbed back into the atmosphere was addressed not too long ago. 


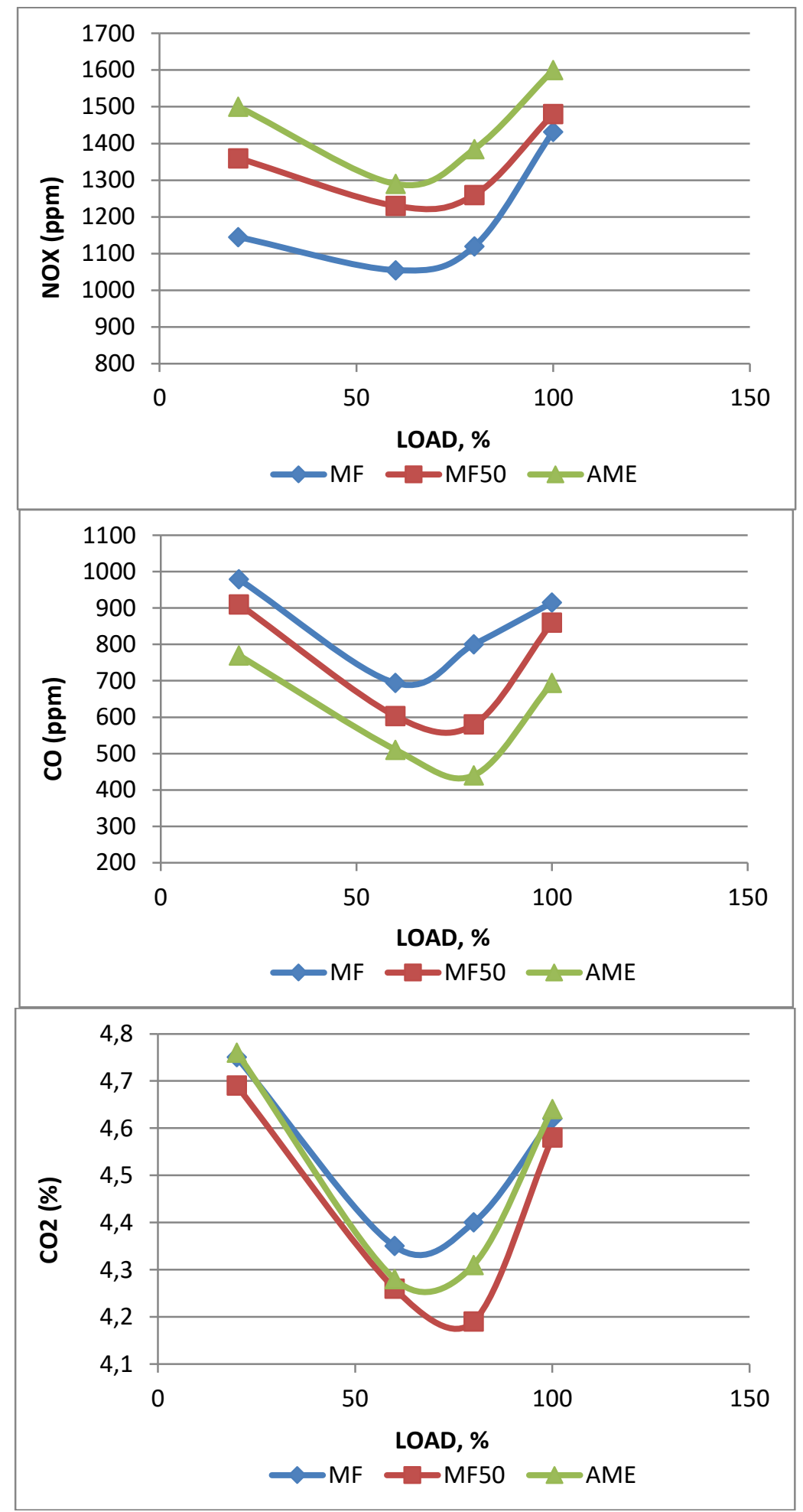

Figure 5. CO2, CO, NOx emissions variation.

Figure 6 and Figure 7 show power and load variation with engine loads with AME content. Cetane number of AME varies with the feed stock used, but it is generally in the higher end of the typical diesel fuel range. The cetane number of AME was higher than the other fuels. The SFC is described as the quantity of fuel consumed per unit of power. Fuel consumption of AME at all engine speeds was higher than that of the other fuels. On average, the AME \% in the mixtures was connected with an increase in the specific fuel consumption. The reason is mainly due to the $11 \%-12 \% \mathrm{O} 2$ content in biodiesel, which results in 
B. Gökalp

lower gross heating values compared with MF. In order to maintain the same power outputs, more biodiesel required, which is compatible with results.

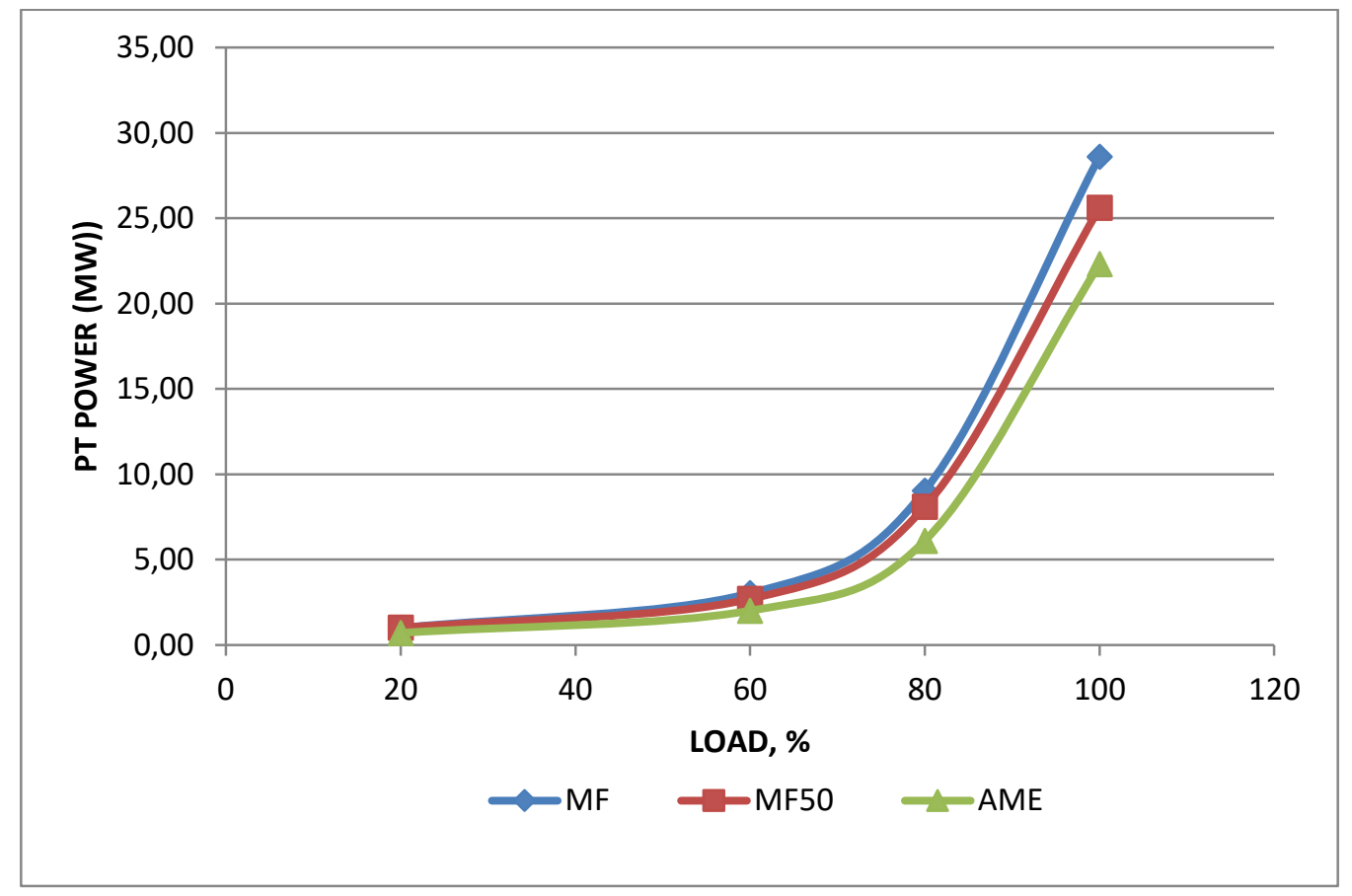

Figure 6. PT power variation.

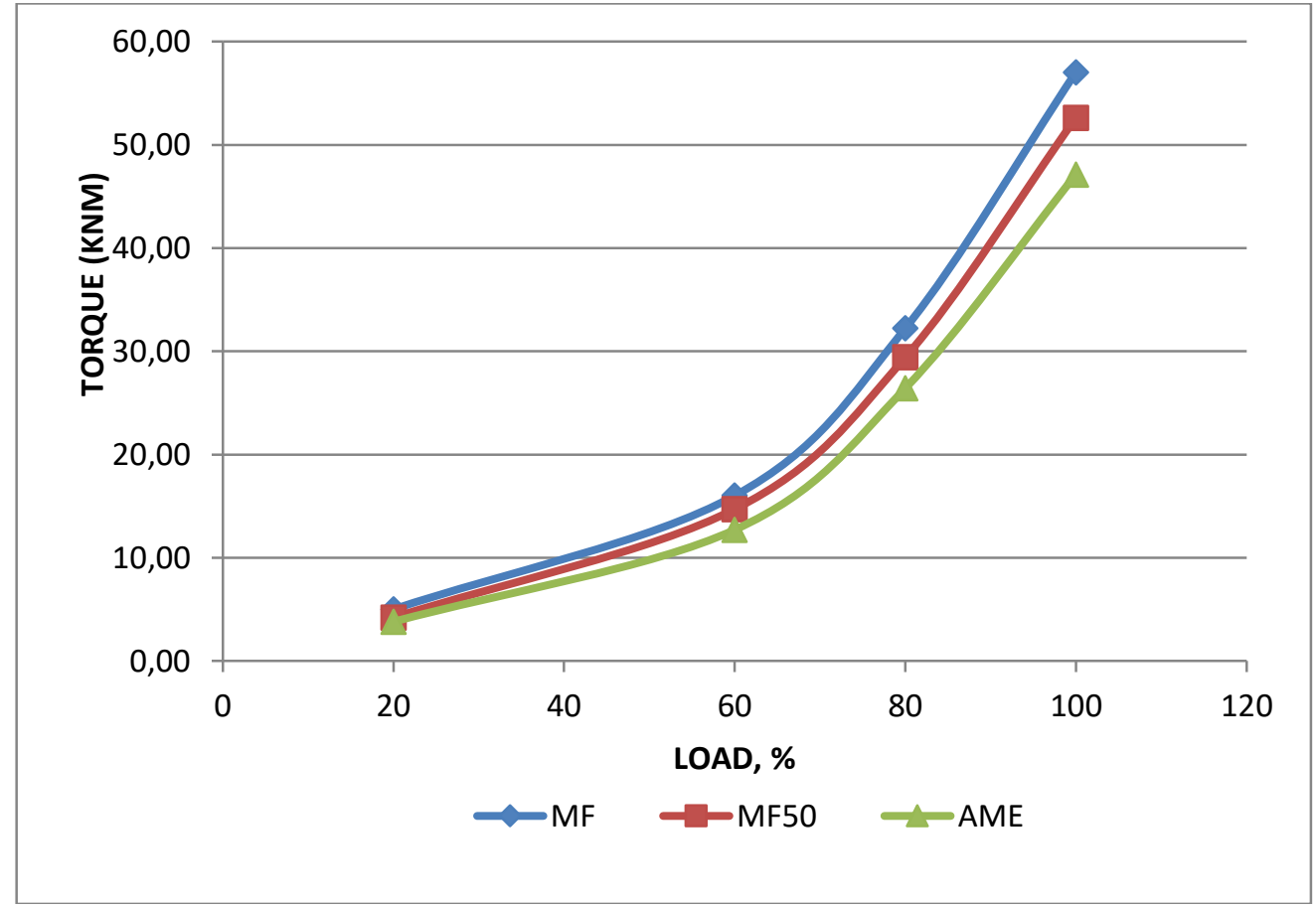

Figure 7. Torque variation. 


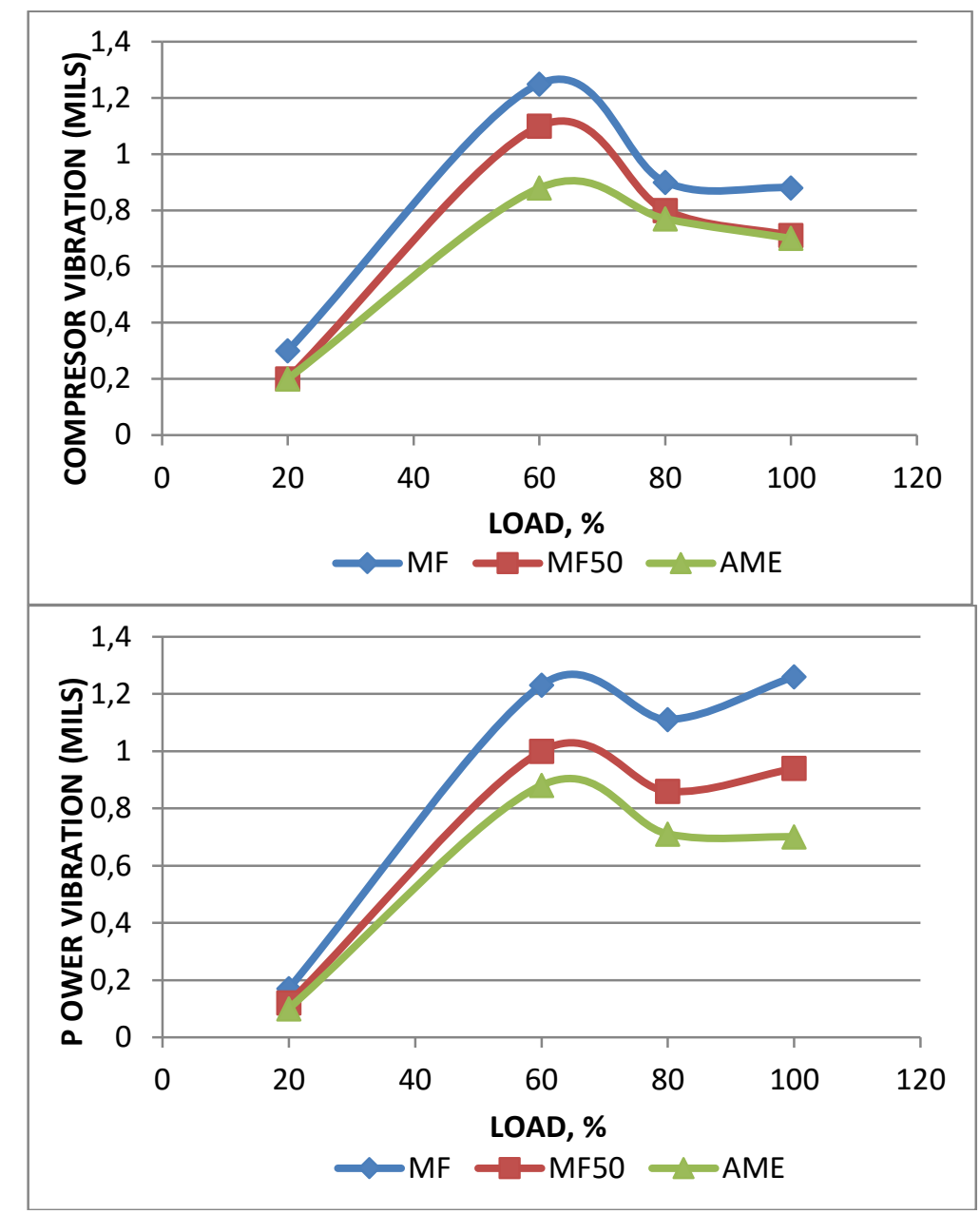

Figure 8. Compressor and power turbine vibration variation.

\section{RESULTS}

This experimental study has pointed that the possibility of widening the applicability of AME blends to support its production and consumption. From the viewpoint of environmental protection and technical feasibility, a $20 \mathrm{MW}$ G/T at high loads were performed with MF and AME, show that AME is considered to be a extra option to alternative fuel for G/T, producing clean exhaust gas. Exhaust temperatures increased with the biodiesel content. The biofuel and its blends used as fuel in G/T led to no noteworthy changes in the engine performance and behaviour compared to MF. The exhaust emissions were assessed for biodiesel and its blends. The results revealed that the use of biodiesel resulted in a slightly lower CO/CO2, higher NO $x$ emissions. Life cycle tests should be accomplished in addition to performance and emissions tests in order to assess the occurrence of no deposit and failure on the engine components.

\section{REFERENCES}

[1] R. Lanzafame, P. F. Scandura, F. Famoso, P. Monforte, C. Oliveri, "Air quality data in Catania: Analysis and Investigation Case study years 2010 - 2011” Energy Procedia, vol. 45: pp. 681-690, 2014.

[2] R. Lanzafame, P. F. Scandura, F. Famoso, P. Monforte, "NO2 concentration analysis in urban area of Catania" Energy Procedia, vol. 45: pp. 671-680, 2014.

[3] P. A. Pilavachi, "Mini and Micro-Gas Turbines for Combined Heat and Power" Appl Therm Engineering, vol. 22: pp. 2003-2014, 2002. 
[4] M. H. Hassan, M. A. Kalam, "An Overview of Biofuel as a Renewable Energy Source: Development and Challenges" Procedia Engineering, vol. 56: pp. 39-53, 2010.

[5] K. K. Gupta, A. Rehman and R. M. Sarviya, "Bio-fuels for the Gas Turbine: A review" Renewable and Sustainable Energy Reviews, vol. 14: pp. 2946-2955, 2010.

[6] S. Brusca, V. Chiodo, A. Galvagno, R. Lanzafame, A. Marino Cugno Garrano, "Analysis of reforming gas combustion in Internal Combustion Engine” Energy Procedia, vol. 45: pp. 899-908, 2014.

[7] N. N. A. N. Yusuf, S. K. Kamarudin and Z. Yaakub, “Overview on the Current Trends in Biodiesel Production” Energy Conversion and Management, vol. 52 (7): pp. 2741-2751, 2011.

[8] Y. S. Kim, J. J. Lee, T. S. Kim, J. L. Sohn, "Effects of syngas type on the operation and performance of a gas turbine in integrated gasification combine cycle" Energy Conversion and Management, vol. 52: pp. 2262-2271, 2011.

[9] D. Korres, D. Karonis, E. Lois, M. B. Linck, A. K. Gupta “Aviation fuel jet fuel and biodiesel on a diesel engine” Fuel, vol. 87: pp. 70-78, 2008.

[10] P. Arkoudeas, S. Kalligeros, F. Zannikos, G. Anastopoulos, D. Karonis, E. Lois "Study of using JP-8 aviation fuel and biodiesel in CI engine” Energy Conversion \& Management, vol. 44: pp. 1013-1025, 2003.

[11]D. Chiaramonti, A. M. Rizzo, A. Spadi, M. Prussi, G. Riccio and F. Martelli, "Exhaust Emissions from Liquid Fuel Micro Gas Turbine Fed with Diesel Oil, Biodiesel and Vegetable Oil” Applied Energy, vol. 101: pp. 349-356, 2013.

[12] J. B. Heywood, "Internal combustion engine Fundamentals” McGraw-Hill: New York, 1988.

[13]D. J. Patterson and N. A. Henein, "Emissions from Combustion Engines and Their Control" Ann Arbor Science Publishers: Ann Arbor: Michigan, USA, 1972.

[14] R. Chacartegui, M. Torres, D. Sánchez, F. Jiménez, A. Muñoz, T. Sánchez, “Analysis of main gaseous emissions of heavy duty gas turbines burning several syngas fuels" Fuel Processing Technology, vol. 92: pp. 213-220, 2011.

[15] M. S. Graboski and R. L. McCormick, "Combustion of fat and vegetable-oil derived fuels in diesel engines" Progress Energy Combustion Science, vol. 24: pp. 64-125, 1998.

[16] R. Chacartegui, M. Torres, D. Sánchez, F. Jiménez, A. Muñoz, T. Sánchez “Analysis of main gaseous emissions of heavy duty gas turbines burning several syngas Fuels” Fuel Processing Technology, vol. 92: pp. 213-220, 2011.

[17] Y. S. Kim, J. J. Lee, T. S. Kim, L. Sohn "Effects of syngas type on the operation and performance of a gas turbine in integrated gasification combine cycle” Energy Conversion and Management, vol. 52: pp. 2262-2271, 2011 